\title{
ANALYSIS OF FACTORS INFLUENCING MICROSTRUCTURE AND MECHANICAL PROPERTIES OF AUSTEMPERED DUCTILE IRON
}

The paper deals with some factors influencing microstructure and mechanical properties of austempered ductile iron (ADI). Final structure and properties of ADI are obtained by exactly controlled process of heat treatment of nodular cast iron. The influence of conditions of isothermal heat treatment on microstructure and mechanical properties of austempered ductile iron, especially different temperature of isothermal transformation of austenite and different holding time at this temperature, is shown in the paper.

\section{Introduction}

Austempered ductile iron (ADI) is new, perspective construction material with an excellent combination of strength, plasticity and toughness. Special properties of ADI are given by unique structure of matrix which is created by acicular ferrite and retained austenite. Technical literature often describes this matrix as bainite (although it does not contain carbides). The matrix is also referred to as ausferrite microstructure (high carbon austenite + ferrite). The structure of ADI is obtained by exactly controlled process of heat treatment of nodular cast iron (Fig. 1) [1,2].

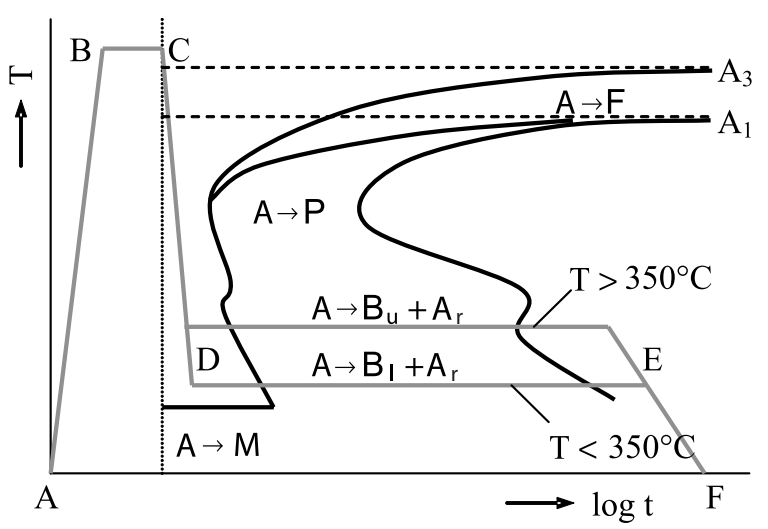

Fig. 1 Process of isothermal heat treatment in the diagram of isothermal transformation of austenite

The isothermal heat treatment consists of the following stages:

- heating to the austenitization temperature $(\mathrm{AB})$;

- holding time at the austenitization temperature (BC);

- quick cooling to the temperature of isothermal transformation of austenite (CD) so that no other transformation of austenite is carried out before reaching the temperature of isothermal transformation;

- holding time at this temperature (DE) until austenite is transformed into bainite;

- cooling to the ambient temperature (EF) which is usually realized slowly in order to prevent formation of stress [3].

The final structure and properties of austempered ductile iron are dependent on the following metallurgical factors:

- microstructure of initial nodular cast iron - nodular cast iron has to have perfectly-nodular graphite with the nodularity higher than $80 \%$ and the count of graphitic nodules higher than 150 $\mathrm{mm}^{-2}$ and it usually has fine-grained pearlite-ferritic matrix. The structure has to be without free carbide, segregation, porosity and other casting defects;

- basic chemical composition - the content of carbon and silicon is dependent on the wallthickness of cast (the content of carbon ranges from $3.3 \%$ for the wallthickness of $100 \mathrm{~mm}$ up to $3.7 \%$ for the wallthickness of 5 to $25 \mathrm{~mm}$, the content of silicon is from $1.9 \%$ for the wallthickness of $100 \mathrm{~mm}$ up to $2.4 \%$ for the wallthickness of 5 to $25 \mathrm{~mm}$ ), the content of manganese should be lower than $0.2 \%$ because it causes the occurrence of martensite at grains boundaries;

- austenitization temperature and holding time at this temperature - they shall insure homogeneous austenitic matrix. The austenitization temperature is chosen in the range from 820 to $950{ }^{\circ} \mathrm{C}$ in dependence on the content of carbon. Higher temperature causes higher hardness, lower temperature causes higher tensile strength and good elongation. Holding time at the austenitization temperature is usually from 1 to 3 hours and it depends on an initial structure of nodular cast iron. High content of ferrite in matrix before the heat treatment lengthens the holding time; pearlitic matrix needs shorter holding time than ferritic;

\footnotetext{
* Alan Vasko

Department of Material Engineering, Faculty of Mechanical Engineering, University of Zilina, Slovakia, E-mail: alan.vasko@fstroj.uniza.sk
} 
- cooling rate to the temperature of isothermal transformation of austenite - a cooling rate has to be quick enough to prevent the occurrence of undesirable ferrite and pearlite;

- temperature of isothermal transformation of austenite and holding time at this temperature - they both determine the final structure and properties of $\mathrm{ADI}$ in a decisive way. The temperature of isothermal transformation is usually within 250 and $450{ }^{\circ} \mathrm{C}$. At higher temperatures $\left(350\right.$ to $450{ }^{\circ} \mathrm{C}$ ) it is possible to obtain ADI with lower strength and hardness but higher elongation and toughness and better fatigue characteristics. At lower temperatures $\left(250\right.$ to $350{ }^{\circ} \mathrm{C}$ ) it is possible to get ADI with higher strength, hardness and abrasion resistance but lower elongation and toughness. The holding time at temperature of isothermal transformation of austenite is within 0.5 and 4 hours when austenite is transformed into upper or lower bainite;

- alloying elements - they have strong influence on quality and properties of ADI. Some of them (for example copper, molybdenum or nickel) decrease a critical cooling rate by moving the diagram of isothermal transformation of austenite to the right $[4,5]$.

\section{Experimental material and methods}

The influence of conditions of isothermal heat treatment on microstructure and mechanical properties of austempered ductile iron was searched on several sets of specimens which were different in temperature of isothermal transformation of austenite and holding time at this temperature.

Experimental material was cast in the electric induction furnace ISTOL. The basic charge was formed by pig iron, steel scrap and additives for the control of chemical composition. FeSiMg7 modifier was used for modification and FeSi75 inoculant was used for inoculation.

Ferrite-pearlitic nodular cast iron was used as basic material for isothermal heat treatment. Chemical composition of the basic material is presented in Tab. 1.

The austenitization temperature was $920^{\circ} \mathrm{C}$ and the holding time at this temperature was 30 minutes. The isothermal transformation of austenite was realized in AS 140 salt bath at the temperatures $420,380,320$ a $250{ }^{\circ} \mathrm{C}$ and the holding time at this temperature was from 30 to 300 minutes (by $30 \mathrm{~min}$.) [6,7].

Chemical composition of basic material

Table 1

\begin{tabular}{|l|c|c|c|c|c|c|c|}
\hline Element & $\mathrm{C}$ & $\mathrm{Si}$ & $\mathrm{Mn}$ & $\mathrm{S}$ & $\mathrm{P}$ & $\mathrm{Cu}$ & $\mathrm{Ni}$ \\
\hline content (weight \%) & 2.78 & 4.69 & 0.49 & 0.017 & 0.050 & 0.92 & 1.10 \\
\hline
\end{tabular}

The metallographic analysis of specimens of basic material (after casting) and specimens after isothermal heat treatment was made by the light metallographic microscope Neophot 32. The microstructure was evaluated by STN EN ISO 945 (STN 42 0461) and by image analysis (using Lucia software) [8, 9].
The tensile test was made by STN EN 10002-1 by means of the testing equipment ZDM 30 with loading range $F=0$ to $50 \mathrm{kN}$. The Rockwell hardness test was made by STN EN ISO 6508-1 by means of the testing equipment LECO LR-3E with a diamond cone forced into specimens under the load $F=1471 \mathrm{~N}$ (150 kp). The measured values of Rockwell hardness were converted to Brinell hardness by STN EN ISO 18265.

The fatigue tests were made by STN 420362 at high-frequency sinusoidal cyclic push-pull loading (frequency $f \approx 20 \mathrm{kHz}$, load ratio $R=-1$, temperature $T=20 \pm 5{ }^{\circ} \mathrm{C}$ ) using the ultrasonic testing equipment KAUP-ZU and the testing procedures.

The mechanical tests were realized on specimens made from basic material (after casting) and material after isothermal heat treatment.

\section{Experimental results}

\subsection{Metallographic analysis}

From the microstructural point of view the basic material (after casting) is ferrite-pearlitic nodular cast iron (Fig. 2) with 57\% content of ferrite in a matrix, the size of graphite within 15 and 60 $\mu \mathrm{m}$ and count of graphitic nodules $205 \mathrm{~mm}^{-2}$. Graphite occurs only in a perfectly-nodular (80\%) and imperfectly-nodular (20\%) shape.

After isothermal heat treatment ADI was obtained. The specimens after isothermal heat treatment with the temperature of isothermal transformation of austenite 420 and $380^{\circ} \mathrm{C}$ have a matrix created by upper bainite and retained austenite (Fig. 3). The specimens after isothermal heat treatment with the temperature of isothermal transformation of austenite 320 and $250{ }^{\circ} \mathrm{C}$ have a matrix created by lower bainite and retained austenite (Fig. 4). The content of retained austenite is slightly decreased with increasing holding time in all sets of specimens. The shape, size and count of graphitic nodules in the specimens after isothermal heat treatment are not changed in comparison with the specimen of basic material (after casting)

\subsection{Mechanical properties}

The changes in microstructure of specimens after isothermal heat treatment caused a change in mechanical properties.

Tensile strength of the basic material (ferrite-pearlitic nodular cast iron) is $711 \mathrm{MPa}$, hardness of the basic material is $250 \mathrm{HB}$. The isothermal heat treatment induced considerable improvement of tensile strength and hardness in comparison with the basic material. The tensile strength and hardness of the specimens after isothermal heat treatment are increased with a decreasing temperature of isothermal transformation of austenite (Tab. 2). The hardness is decreased with an increasing holding time at the temperature of isothermal transformation of austenite in all sets of specimens (Fig. 5). 


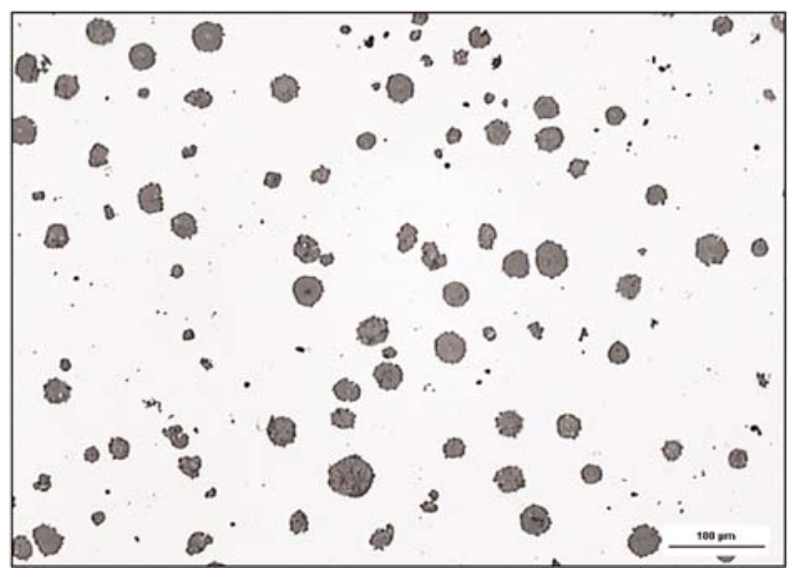

a) non-etched

Fig. 2 Microstructure of basic material (after casting) - ferrite-pearlitic nodular cast iron

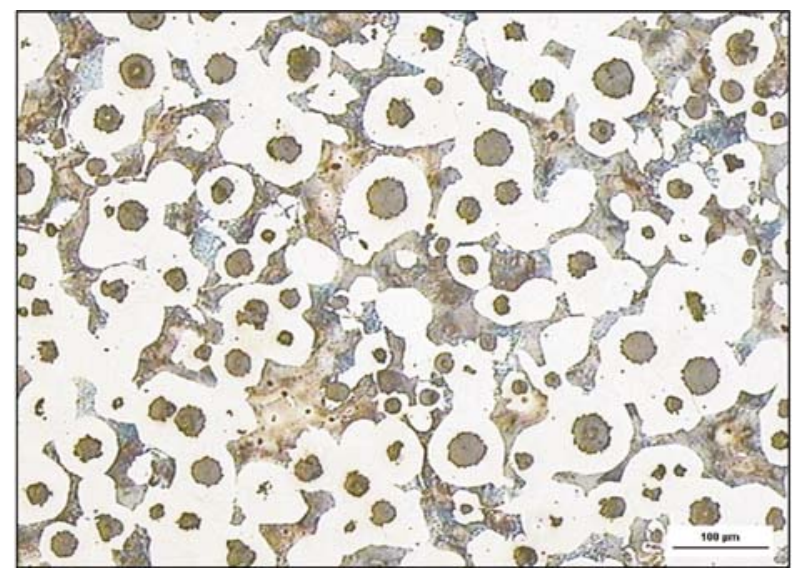

b) etched by $3 \%$ Nital + pikric acid

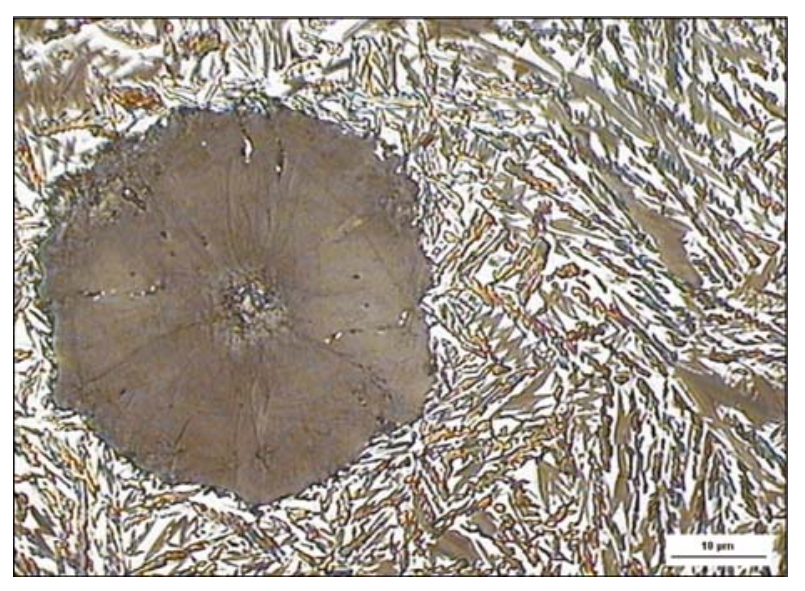

a) etched by $3 \%$ Nital

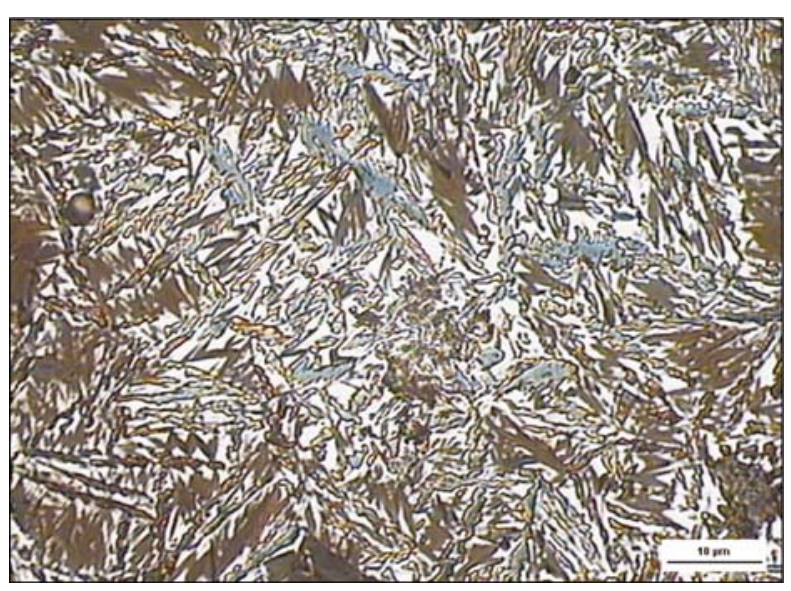

b) etched by Klemm I

Fig. 3 Microstructure of specimens after isothermal heat treatment $-380^{\circ} \mathrm{C} / 60^{\prime}, \mathrm{ADI}-$ matrix created by upper bainite and retained austenite

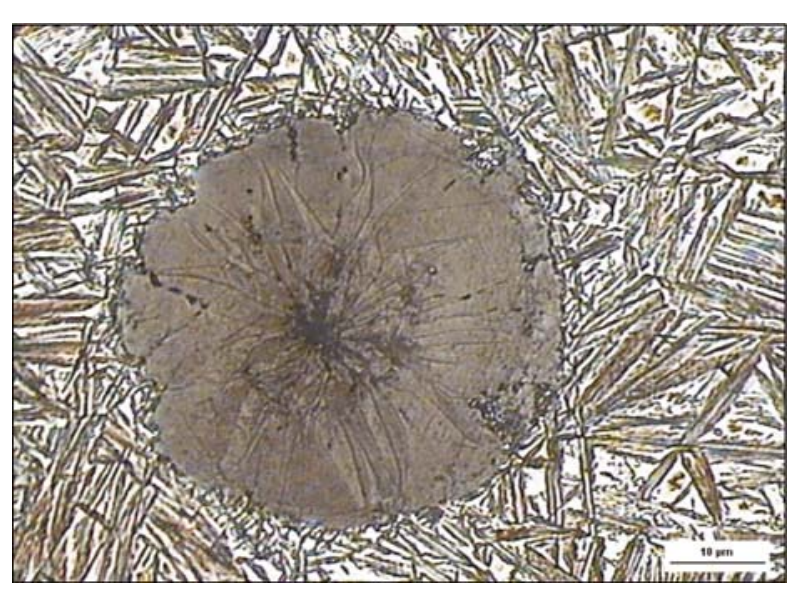

a) etched by $3 \%$ Nital

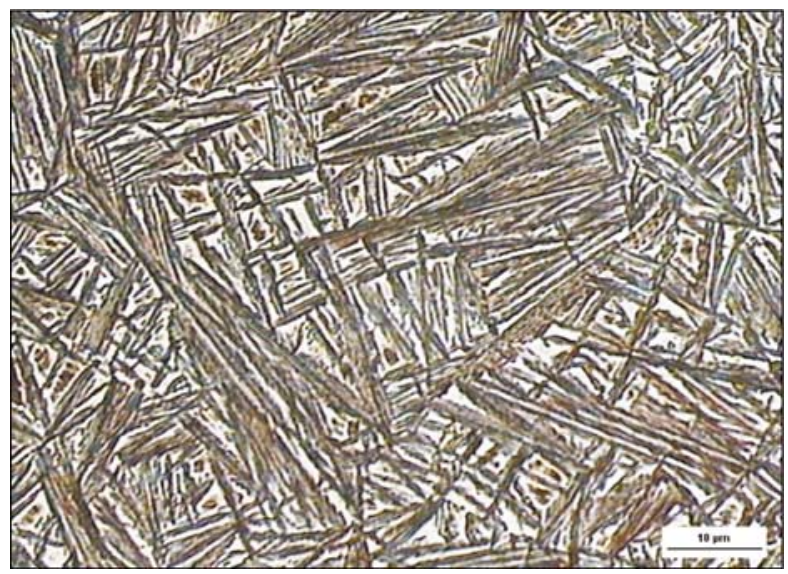

b) etched by Klemm I

Fig. 4 Microstructure of specimens after isothermal heat treatment - $320^{\circ} \mathrm{C} / 60^{\prime}, \mathrm{ADI}-$ matrix created by lower bainite and retained austenite 
Fatigue strength of the basic material is about $390 \mathrm{MPa}$. The isothermal heat treatment induced a decrease of fatigue properties in comparison with the basic material. Fatigue endurance of the specimens after isothermal heat treatment is decreased with a decreasing temperature of isothermal transformation of austenite.

Mechanical properties of chosen specimens

Table 2

\begin{tabular}{|c|c|c|c|c|}
\hline Specimen & Matrix & $\begin{array}{c}\mathrm{R}_{\mathrm{m}} \\
(\mathrm{MPa})\end{array}$ & $\mathrm{HB}$ & $\begin{array}{c}\sigma_{\mathrm{c}} \\
(\mathrm{MPa})\end{array}$ \\
\hline basic material & ferrite + pearlite & 711 & 250 & 390 \\
\hline $420^{\circ} \mathrm{C} / 60^{\prime}$ & \multirow{2}{*}{$\begin{array}{c}\text { upper bainite + retained } \\
\text { austenite }\end{array}$} & 980 & 474 & 378 \\
\hline $380^{\circ} \mathrm{C} / 60^{\prime}$ & & 1040 & 495 & 361 \\
\hline $320^{\circ} \mathrm{C} / 60^{\prime}$ & \multirow{2}{*}{$\begin{array}{c}\text { lower bainite + retained } \\
\text { austenite }\end{array}$} & 1164 & 492 & 328 \\
\hline $250^{\circ} \mathrm{C} / 60^{\prime}$ & & 1551 & 530 & 276 \\
\hline
\end{tabular}

The increase of tensile strength and hardness with a decreasing temperature of isothermal transformation of austenite is caused by a change of matrix from upper bainite to lower bainite. The decrease of fatigue strength with a decreasing temperature of isothermal transformation of austenite is due to the same change of microstructure.

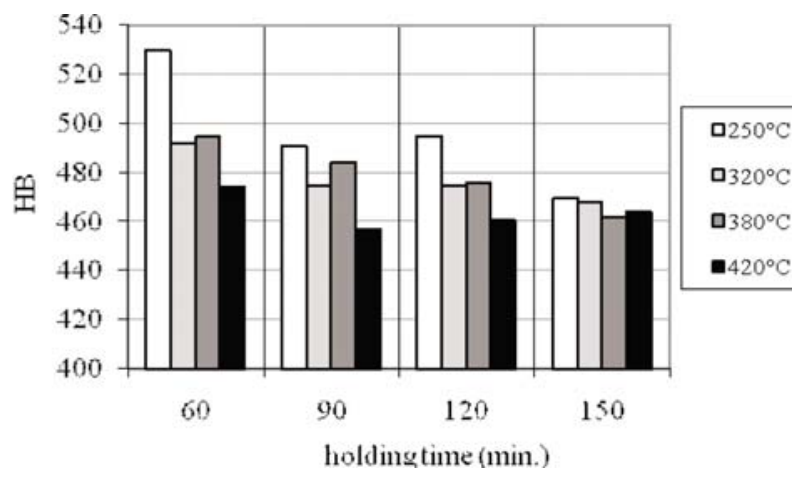

Fig. 5 Influence of temperature of isothermal transformation of austenite and holding time at this temperature on Brinell hardness
The measured values of tensile strength, hardness and fatigue strength correspond to results of similar experiments abroad, for example $[10,11]$.

\section{Conclusion}

Final microstructure and mechanical properties of casts from ADI are markedly dependent on the temperature of isothermal transformation of austenite and holding time at this temperature. Their influence on the microstructure and mechanical properties of ADI can be summarized in following points:

- the specimens with higher temperature of isothermal transformation of austenite have the matrix created by upper bainite and retained austenite and the specimens with lower temperature of isothermal transformation of austenite have the matrix created by lower bainite and retained austenite;

- the content of retained austenite is decreased with increasing holding time at the temperature of isothermal transformation;

- the shape, size and count of graphitic nodules are not changed in dependence on the temperature of isothermal transformation of austenite and in dependence on the holding time at this temperature;

- the tensile strength and hardness of the specimens are increased with decreasing temperature of isothermal transformation of austenite, but the elongation and toughness is decreased;

- the hardness of the specimens is decreased with increasing holding time at the temperature of isothermal transformation;

- the fatigue strength is decreased with decreasing temperature of isothermal transformation of austenite.

The choice of temperature of isothermal transformation of austenite and holding time at this temperature depends on a required combination of mechanical properties.

\section{Acknowledgement}

This work has been supported by the Cultural and Educational Grant Agency of the Ministry of Education of the Slovak Republic, grant No. 3/6078/08 Creation of a laboratory and textbooks for the teaching of the subject "Properties and use of materials".

\section{References}

[1] DORAZIL, E.: Austempered Ductile Iron - ADI (in Czech), Slevarenstvi, Vol. 41, 4/1993, p. 181-183.

[2] SKOCOVSKY, P., BOKUVKA, O., KONECNA, R., TILLOVA, E.: Material Science for Specializations of Mechanical Engineering (in Slovak), EDIS Zilina, 2006.

[3] SKOCOVSKY, P., PODRABSKY, T.: Graphitic Cast Irons (in Slovak), EDIS Zilina, 2005.

[4] GEDEONOVA, Z., JELC, I.: Metallurgy of Cast Irons (in Slovak), HF TU Kosice, 2000.

[5] VECHET, S., KOHOUT, J., KLAKURKOVA, L.: Fatigue Properties of Austempered Ductile Iron in Dependence of Transformation Temperature, Materials Science (Medziagotyra), Vol. 14, 4/2008, p. 324-327.

[6] VASKO, A., KOPAS, P.: Influence of Conditions of Isothermal Heat Treatment on Microstructure and Mechanical Properties of Austempered Ductile Iron (ADI), In: TRANSCOM 2007, Section 6, Zilina, 2007, p. 255-258. 
[7] KOPAS, P., HANZLIKOVA, K., ZAPLETAL, J., VASKO, M.: Influence of Heat Treatment and Chemical Composition on Mechanical Properties of ADI (in Slovak), In: Nekonvencne technologie 2006, Zilina, 2006, p. 1/18-9/18.

[8] SKOCOVSKY, P., VASKO, A.: Quantitative Evaluation of Structure of Cast Irons (in Slovak), EDIS Zilina, 2007.

[9] BELAN, J.: Quantitative Metallography of Mechanical Worked Ni-base Superalloys (in Slovak), Acta Mechanica Slovaca, Vol. 12, No. 3-A, 2008, p. 33-38.

[10] SALMAN, S. - FINDIK, F. - TOPUZ, P.: Effects of Various Austempering Temperatures on Fatigue Properties in Ductile Iron, Materials and Design, Vol. 28, 7/2007, p. 2210-2214.

[11] KIM, Y. J. - SHIN, H. - PARK, H. - LIM, J. D.: Investigation into Mechanical Properties of Austempered Ductile Cast Iron (ADI) in Accordance with Austempering Temperature, Materials Letters, Vol. 62, 3/2008, p. 357-360. 